\title{
Criminal Actions Based on the Living Law in Draft-Criminal Code: Degradation of the Concept
}

\author{
Deni Setya Bagus Yuherawan ${ }^{1 *} \quad$ Trisusilowati $^{2} \quad$ Romlan Prasodjo $^{2} \quad$ Joice Soraya $^{3}$ \\ 1. Law Faculty of Trunojoyo Madura University, Bangkalan, Indonesia \\ 2. Law Faculty of Darul Ulum University, Jombang, Indonesia \\ 3. Law Faculty of PGRI Kanjuruhan University, Malang, Indonesia
}

\begin{abstract}
This article intends to analyze the degradation concept of the additional penalty of 'fulfillment of local customary obligations' of 'prohibited acts' based on 'laws living in the community (living law)' compared to the principal penalty in 'criminal acts' based on 'statute criminal law'. The legal materials analyzed include Article 1; Article 2; Article 64 letter b; Article 65 paragraph (1) and (2); Article 66 paragraph (1) and (2); Article 97; and Article 597 paragraph (1) and (2) Draft-Criminal Code. The research used is legal research with the type of doctrinal research. The formulation of the problem will be discussed using a statutory approach and a conceptual approach. Analysis of legal materials uses prescriptive analysis to find arguments about the degradation of the concept. Discussion of the formulation of the problem can be concluded that there has been a degradation in the concept of an additional penalty of 'the fulfillment of local customary obligations' and 'prohibited acts' based on 'living law' compared to principal and additional penalty and 'criminal acts' based on 'statute criminal law'. 'Prohibited acts' based on 'living law' as a concept equivalent to criminal acts based on statute criminal law are subject to concept degradation, due to 'fulfillment of local customary obligations' for prohibited acts is only positioned as an additional and complementary punishment from a necessity to the level of the principal penalty.
\end{abstract}

Keywords: degradation; prohibited act; criminal act; living law; statute criminal law

DOI: $10.7176 / \mathrm{JLPG} / 112-02$

Publication date:August $31^{\text {st }} 2021$

\section{Introduction}

This article needs to analyze several important articles in the Draft Criminal Code, namely Article 1; Article 2; Article 64 letter b; Article 65 paragraph (1) and (2); Article 66 paragraph (1) and (2); Article 97; and Article 597 paragraph (1) and (2). Article 1 The Draft Criminal Code provides:

(1) There is no act that can be subject to penal sanctions and/or treatment except for the strength of statute criminal laws that existed before the criminal act was committed.

(2) In determining the existence of a crime, the analogy is prohibited.

In Article 1 paragraph (1) of the Draft Criminal Code, using a systematic interpretation, there is no doubt that what is meant by the phrase 'there is no act that is subject to penal sanctions, what is meant by 'a criminal act', which is emphasized again in paragraph (2) by the phrase 'the existence of a criminal act'. Article 2 paragraph (1) of the Draft Criminal Code provides:

(1) The provisions referred to in Article 1 paragraph (1), namely: do not reduce the validity of the 'living law' which determines that a person should be sentenced even though the offense is not regulated in this Law.

(2) 'Living law' as referred to in paragraph (1) shall apply in the place where the law lives and as long as it is not regulated in this Law and following the values contained in Pancasila, the 1945 Constitution of the Republic of Indonesia, human rights, and general legal principles recognized by civilized nations.

The phrase 'that a person deserves to be convicted (Article 2 paragraph 1 of the Draft-Criminal Code) is associated with the phrase no act is subject to penal sanctions and the phrase 'the existence of a criminal act' (Article 1 of the Draft-Criminal Code) further emphasizes that the concept what is meant is a 'criminal act'. Article 597 of the Draft Criminal Code, determines:

(1) Any person who commits an act which according to the 'living law' is declared a prohibited act, shall be punished by penal sanction.

(2) The punishment as referred to in paragraph (1) shall be in the form of fulfillment of the customary obligations as referred to in Article 66 paragraph (1) letter $\underline{\mathrm{f}}$.

In Article 597 paragraph (1) of the Draft-Criminal Code, the phrase used is "an act which according to the 'living law' is declared a prohibited act". Thus, the concept used is 'prohibited acts'. In the three articles above, there are different concepts in one unified system in the Draft-Criminal Code, namely "criminal acts" and "prohibited acts". The problem arises, namely whether the two terms are only different terms with the same substance or indeed the substance is different. The elucidation of Article 1 paragraph (1) of the Draft-Criminal Code emphasizes the use of the concept of a 'criminal act', namely: ... which determines that an offense is a criminal act if determined by or based on statute law. ... Therefore, statute criminal law containing penal sanction 
threats must be in place before a criminal act is committed...

Elucidation of Article 2 of the Draft-Criminal Code also uses the concept of 'criminal acts', namely: ... what is meant by the 'living law' which determines that a person should be sentenced" is a customary criminal act. ... Which determines that someone deserves to be convicted. To provide a legal basis regarding the enforcement of customary criminal acts .... This compilation contains 'living law' that qualifies as customary offenses (paragraph 1). In this provision, what is meant by "applies in a place where the law lives" is that it applies to any person who commits a customary offense in that area. This paragraph contains guidelines in establishing customary criminal law.... (paragraph 2).

The elucidation of Article 597 of the Draft Criminal Code is stated to be "quite clear". Thus, the elucidation of the article recognizes the concept of "prohibited acts" in Article 597 of the Draft-Criminal Code. Observing the concept of 'criminal acts' (Article 1 of the Draft Criminal Code) and 'prohibited acts' (Article 597 of the Draft-Criminal Code) raises legal problems, namely whether the two concepts are 'contradictio in terminis' (contradiction in terms), 'contradiction in concept' or 'degradation in concept'. Based on legal problems, it is necessary to formulate the following legal problems: is it true that there has been a degradation in the concept of 'prohibited act' compared to 'criminal act'?

\section{Legal Materialsand Methods}

In this article, the research used is legal research with the type of doctrinal research. The formulation of the problem will be discussed using a statutory approach and a conceptual approach. Analysis of legal materials uses prescriptive analysis to find arguments about the degradation of the concept.

\section{Result and Discussion}

\subsection{Degradation of the Concept of 'Prohibited Acts' versus 'Criminal Acts'}

It has been explained that a 'prohibited act' is an act which according to the 'living law' is punishable by penal sanction, according to the provisions of Article 597 paragraph (1) of the Draft-Criminal Code. According to paragraph (2), the penal sanction referred to in paragraph (1) is in the form of 'fulfillment of customary obligations'. The construction of article 597 of the Draft Criminal Code does not recognize the concept of a "criminal act", but only a "prohibited act" with a penal sanction as an additional penalty in the form of "fulfillment of customary obligations".

There is a change in concept, from 'fulfillment of customary obligations' to 'fulfillment of local customary obligations' as stipulated in Article 66 paragraph (1) letter $\underline{f}$ of the Draft Criminal Code, that the additional penalties referred to in Article 64 letter $\underline{b}$ consist of: (a) revocation of rights certain; (b) confiscation of certain goods and/or claims; (c) announcement of the judge's decision; (d) compensation payments; (e) revocation of certain licenses; and (f) fulfillment of local customary obligations.

Article 66 paragraph (1) letter $\underline{f}$ of the Draft-Criminal Code emphasizes that the concept of "fulfillment of local customary obligations" is a logical consequence of "prohibited acts". 'Prohibited acts' and 'fulfillment of local customary obligations' are concepts of equal standing. Article 66 paragraph (2) of the Draft Criminal Code stipulates that additional penalties as referred to in paragraph (1) may be imposed if the imposition of the principal penalty is not sufficient to achieve the purpose of the punishment. The provisions of this article place an additional penalty in the form of 'fulfillment of local customary obligations' as a complement to the fulfillment of the purpose of the punishment.

Article 97 of the Draft Criminal Code stipulates that "additional punishment in the form of fulfilling local customary obligations can be imposed even though it is not a formulation of a criminal act with due regard to the provisions of Article 2 paragraph (2)". 'Additional penalties' are regulated in Article 64 of the Draft Criminal Code, which stipulates that: penalties consist of: (a) principal penalties; (b) additional penalties; and (c) special crimes for certain crimes stipulated in the law. As for the main crime, it is regulated in Article 65 Draft Criminal Code. In 65 paragraph (1) the Draft Criminal Code stipulates: the principal penalties referred to in Article 64 letter consist of: (a) imprisonment; (b) closure; (c) criminal supervision; (d) a fine; and (e) social work punishment. Meanwhile, paragraph (2) determines that the order of punishment as referred to in paragraph (1) determines the severity or lightness of the sentence.

Systematically, Article 64 letter b; Article 65 paragraph (1) and (2); Article 66 paragraph (1) and (2); Article 97; and Article 597 paragraphs (1) and (2) of the Draft Criminal Code affirms that "prohibited acts" based on 'living law' are prohibited from applying the principal penalty. This means that there is a prohibition on the application of the principal penalty. What is allowed is to apply an additional penalty, in the form of 'fulfillment of local customary obligations'.

Based on the provisions of the articles above, there are a separation of the following concepts: (1) Criminal acts based on statute criminal law with the threat of principal and additional penalties (including 'fulfillment of local customary obligations') and (2) 'prohibited acts' based on 'living law' with the additional penalty, in the form of 'fulfillment of local customary obligations'. This sorting of concepts must be linked to the essence of 
Article 2 of the Draft-Criminal Code. Article 2 The Draft Criminal Code stipulates: (1) the provisions referred to in Article 1 paragraph (1) do not reduce the validity of 'living law' which determines that a person should be sentenced even though the act is not regulated in this Law; and (2) the 'living law' as referred to in paragraph (1) applies in the place where the law lives and as long as it is not regulated in this Law and is following the values contained in Pancasila, the Constitution of the Republic of Indonesia 1945, human rights and general principles recognized by civilized nations. The meaning of Article 2 of the Draft Criminal Code can be concluded from the following phrases:

a. The meaning of the phrase 'provision as referred to in Article 1 paragraph (1) does not reduce', that in addition to the criminal law (Article 1 Draft-KUHP) there is another basis for qualifying an act as a criminal act;

b. The meaning of the phrase "the validity of the 'living law' which determines that a person should be convicted even though the act is not regulated by law" that "the "living law'" is the basis for qualifying whether the act should be punished;

c. The meaning "applies in a place where the law lives" that the 'living law' is in the area, is local;

d. The meaning of 'as long as it is not regulated in this Law', that the existence of a 'living law' depends on the criminal law concerned;

e. The meaning of by the values contained in Pancasila, the 1945 Constitution, human rights, and general legal principles recognized by civilized nations, there is a necessity that 'living law' must not conflict with critical norms in values is contained in Pancasila, the 1945 Constitution, human rights, and general legal principles recognized by civilized nations.

It turns out that the concept of "living law" is quite complex to understand and implement. The series of meanings in Article 2 of the Draft-Criminal Code are as follows: "living law" is the basis for qualifications and whether or not an act is punishable. The enactment of "the living law" is a locality, because it applies to the place where the "living law" is. "Living law" can be corrected and is not enforced by statute criminal law. The substance of "living law" must be in harmony and must not conflict with the values contained in Pancasila, the 1945 Constitution, human rights, and "general legal principles recognized by civilized nations". This article is focused on the concept of "statute law does not reduce the validity of living law" as well as "general law principles recognized by civilized nations" and the nature of locality of 'living law'.

As explained in Article 2 paragraph (1) of the Draft Criminal Code: statute law does not reduce the validity of 'living law' that determines that a person should be convicted even though the act is not regulated in law. The phrase that needs to be considered is "the statute law does not reduce the validity of the living law". Besides, it is necessary to analyze whether the position of the statute law is equal to or higher than the 'living law'. Equality or inequality is a measurement concept. According to KBBI (the Big Indonesian Dictionary), the definition of measure is a dose. Another term for 'measure' is grade. The meaning of 'grade' includes value, price, and level. In the context of the article above, the meaning of measurement is the level (size and level).

Returning to the problem of the phrase "the statute law does not reduce the validity of the living law". To understand the phrase must use a grammatical meaning. Grammatical means according to or according to grammar. Grammatical meaning is defined as the meaning that has undergone a process of affixation, reduplication, composition, or making a sentence, namely the meaning of words that change according to the context (about the situation, namely the place, time, and environment in which the language of the user is used).

To understand a sentence must use "grammatical competence". Grammatical competence refers to Chomsky's linguistic competence and is "as formal as possible" according to Hymes. Grammatical competence is the grammatical and lexical ability of a person's language mastery. This competence is needed to understand and express the meaning of an utterance. Grammatical competence must understand sentences using the concept of "grammatical cohesion", a semantic relationship between elements marked by grammatical tools, namely the language tools used concerning grammar.

The phrase "statute law does not reduce the validity of living law" consists of lexical and grammatical meanings, namely " statute law" as a lexical meaning, and "not reducing" and "the enactment of living law" as grammatical meanings. "Not reducing" means that there is no process of reducing the level of legal concept. There is no degradation process', namely regression, deterioration, and a decrease in the quality of the intended enforceability of living law. "The enactment of living law" means that living laws are still and are in effect. The grammatical meaning of the sentence 'statute laws do not reduce the validity of living law' is that laws do not at all reduce the level of validity of living law. Thus "statute laws" and "living law" have an equal position, in equal measure.

The next phase that needs to be analyzed is the general principle of law recognized by civilized nations. The phrase 'general principle of law recognized by civilized nations' was first regulated in the Statute of the International Court of Justice (ICJ), 18 April 1946. Article 38 paragraph (1) ICJ regulates: The Court, whose function is to decide by international law such as disputes as are submitted to it, shall apply:

a. international conventions, whether general or particular, establishing rules expressly recognized by the 
contesting states;

b. international custom, as evidence of a general practice accepted as law;

c. the general principles of law recognized by civilized nations;

d. subject to the provisions of Article 59, judicial decisions, and the teachings of the most highly qualified publicists of the various nations, as a subsidiary, means for the determination of rules of law.

Article 38 (1) ICJ is a source of international law used by the ICJ to adjudicate cases, namely: (1) International treaties, both general and specific; (2); International custom; (3) General principles of law recognized by civilized nations; and (4) court decisions and opinions of experts from various countries as additional sources of international law). The meaning of Article 38 paragraph (1) of the ICJ can be understood as follows: "requires the Court to apply as sources, in the first instance, (1) treaties and (2) customary international law. However, this same article also authorizes the court to apply "the general principles of law recognized by civilized nations". Thus, should neither treaty nor custom proves adequate to resolve a contentious question, resort may be had to "general principles" as a subsidiary source. This means that: ... requires the Court to apply as a source of (1) treaties and (2) customary law. However, this same article also empowers courts to apply "general principles of law recognized by civilized nations. Thus, if treaties or customs prove inadequate to resolve disputed issues, it should use" general principles ", as an additional source.

The phrase 'general principle of law recognized by civilized nations' was adopted into the European Convention for the Protection of Human Rights and Fundamental Freedoms, known as the European Convention on Human Rights (EHCR) in 1950. Article 7, which is entitled 'No punishment without law', determines:

(1) No one shall be held guilty of any criminal offense on account of any act or omission which did not constitute a criminal offense under national or international law at the time when it was committed. Nor shall a heavier penalty be imposed than the one that was applicable at the time the criminal offense was committed.

(2) This article shall not prejudice the trial and punishment of any person for any act or omission which, at the time when it was committed, was criminal according to the general principles of law recognized by civilized nations

Paragraph (2) The article stipulates that the enactment of this provision must not override trial and punishment for any person who commits an act either deliberately or negligently which constitutes a crime according to the principles of general law by civilized nations at the time the act was committed. The concept of 'the general principles of law recognized by civilized nations' in Article 38 paragraph (1) of the ICJ and Article 7 paragraph (2) of the EHCR was amended in the United Nations International Covenant on Civil and Political Rights (ICCPR), 1966. In Article 15 paragraph (2) of the ICCPR, there has been a change in concept to become 'the general principle of law recognized by the community of nations, which determines: nothing in this article shall prejudice the trial and punishment of any person for any act or omission which, at the time when it was committed, was criminal according to the general principles of law recognized by the community of nations. The change in the concept, from 'civilized nations' to become a community of nations. This important change was made by removing the word 'civilized'.

The ICCPR was later ratified by Law Number 12 of 2005 concerning the Ratification of the International Covenant on Civil and Political Rights. In the consideration of letter $\underline{\mathrm{d}}$, it is emphasized that the international instruments as referred to in letter $\mathrm{c}$ are not contrary to Pancasila and the 1945 Constitution of the Republic of Indonesia, following the nature of the Republic of Indonesia as a constitutional state that upholds and guarantees human dignity, the equal position of all citizens in law, and the desire of the Indonesian people to continuously promote and protect human rights in the life of the nation and state. Thus, the ICCPR is in line with and does not contradict Pancasila, the 1945 Constitution, and the essence of the rule of law. The substance of the concept 'the general principles of law recognized by civilized nations' is found in the International Legal Research Tutorial, as follows:

Included in the list of sources of international law in Article 38 of the International Court of Justice Statute are "general principles of law recognized by civilized nations" (i.e. general principles of fairness and justice which are applied universally in legal systems around the world). Examples of these general principles of law are laches, good faith, res judicata, and the impartiality of judges. International tribunals rely on these principles when they cannot find authority in other sources of international law.

An important note is found in the phrase 'international tribunals rely on these principles when they cannot find authority in other sources of international law', that if there is no other international legal source authority, then international courts should rely on the application of general legal principles, such as 'laches', 'good faith', 'res judicata', and 'the impartiality of judges'. Another note about the source of international law, namely: these general principles of law can be found in decisions of international tribunals and national courts; references to them may also be found in the teachings of the "most highly qualified publicists" (i.e., eminent international law scholars). Article 38 includes judicial decisions (of both international and national) and scholarly writings as "subsidiary means for the determination of rules of law;" in other words, these are not authorities, rather they 
are evidence of the sources of international law. The note emphasizes that this is not a question of authority, but evidence from international legal sources.

Apart from these legal principles, one of the important legal principles is 'equity'. According to Justice Margaret White: equity, as it has been recognized and developed in international law is most closely related to Western legal traditions. This is no doubt because the body of international law rules was developed in Europe after the Peace of Westphalia in 1648 and the rise of statecraft in Europe in the 19th century. Equity develops in international law, closely related to western legal traditions. This is undoubted because the rule of international law developed in Europe after the Peace of Westphalia in 1648 and the rise of constitutional order in Europe in the 19 th century.

White continued, that equity, so understood, entailed and entails discretionary characteristics both as to its application and its extent - an enduring issue both in domestic and international law. Equity requires and requires discretionary characteristics, for its application and extent. A longstanding issue in both domestic and international law. Ultimately, it is understood that equity can be identified in many societies and religions even if in different forms. The Greeks called it clemency. The Romans termed it aequitas or equality. Ancient Chinese law described it as compassion and in Hindu philosophy is found the doctrine of righteousness. In some Islamic schools', istihsan is employed to avoid undue hardship from the application of the law.

Another idea states: some basic principles of law commonly cited include: The principle of good faith, which is being faithful to a sense of obligation; the bar against a party raising a claim again after it has been settled by judicial decision (res judicata); and the bar that precludes taking a position which is contrary to a position already established either by previous admission or action and legally determined as being true. This idea means that some of the basic principles of law that are often quoted include: 'good faith principle', 'faithfulness to duty'; 'Prohibition of filing a lawsuit against a court decision' (res judicata); and "the prohibition of taking a position that is contrary to a position which has been determined under a prior confession or action and is legally determined to be true". The laws of every civilized nation declare them 'hostis humani generis' ('enemies of all mankind'). The law for every civilized nation declares that opposites are enemies of mankind.

The essence of "the general principles of law recognized by civilized nations", in principle states, that' the laws of every civilized nation declare them 'hostis humani generis'; '. Offenses against it are "hostis humani generis", the common enemy of all mankind. The next thing that needs to be analyzed is the phrase 'civilized nations'. If there is a question about 'civilized', then according to the Collins Dictionary: 'if you describe a society as civilized, you mean that it is advanced and has sensible laws and customs'. What is meant by 'civilized nations' is a society that is advanced and has wise laws and customs.

The meaning of the phrase 'civilized nations', according to the Oxford Public International Law, is:

The phrase 'civilized nations' (also known as 'civilized peoples', 'civilized countries', or, collectively, as the 'civilized world') has long served to distinguish the European Christian States from States not thought to possess similar legal systems or values. Those States which were not considered to possess the attributes of 'civilized nations' have been variously described as 'uncivilized nations', 'semi-civilized nations', 'rude nations', or 'enslaved nations', and their inhabitants as 'barbarians' or 'savages'.

This means that the phrase 'civilized nation', also known as 'civilized society', 'civilized state', or, collectively, as 'a civilized world', has long been used to distinguish a European Christian State from one considered to have no system. or similar legal values. Countries that are not considered to have the attribute 'civilized countries' have been widely described as' uncivilized countries',' semi-civilized countries', 'rough countries', or 'slave countries', and their inhabitants were considered 'barbarians' or' savages'.

An important thing that also needs to be analyzed is the relationship between "the principle of general law recognized by civilized nations" and "the living law ". This linkage is found in the phrase 'the living law... applies in the place where the law lives and as long as it is not regulated in this statute law and following the values contained in ... the general law principles recognized by civilized nations. In this phrase there are several ideas, namely:

a. There is a locality aspect of 'the living law ' because its scope of action is limited to 'where the living law lives';

b. There is a national aspect of the phrase 'and as long as it is not regulated in this Law';

c. The idea of "general legal principles recognized by civilized nations", genuinely, originated and grew in international legal regimes;

d. There are 3 (three) levels of legal enforceability in the Draft Criminal Code, namely: (1) at the level of locality (for 'living law') which only apply to the same place for "prohibited acts"; (2) at the national level (national law) for "criminal acts"; and (3) at the international level ("the principle of general law recognized by civilized nations") for "international crimes";

e. "The principle of general law recognized by civilized nations" is a critical norm, as well as a touchstone for the validity of "living law". As long as 'living law' does not conflict with general law principles recognized by civilized nations, living law is considered to have validity. 
The meaning of 'degradation' is decline, etc. (regarding quality, morals, rank, etc.). In English, one meaning of 'degradation' is 'the act or process of degrading'. It also means 'the process by which something is made worse', a process by which something becomes worse. In the context of this article, the meaning of degradation is a decrease in the level of a legal concept. An analysis of whether or not there is a degradation in the concept of "prohibited acts" compared to "criminal acts", it is necessary to describe the main ideas contained in "prohibited acts" and "criminal acts". The main idea of 'prohibited acts':

1. "Prohibited acts" are acts that contrary to the living law, which are punishable by penal sanction. Not in the form of a principal penalty, but only an additional penalty in the form of "fulfillment of local customary obligations". 'Fulfillment of local customary obligations' is a logical consequence of 'prohibited acts'. Thus, "prohibited acts" and "fulfillment of local customary obligations" are two integrated concepts and equal positions.

2. The penalty of "fulfillment of local customary obligations" is an additional penalty, as a complement to the principal penalty, which is given if it is insufficient to achieve the stated objectives of the principal penalty.

The main idea of 'criminal acts' can be summarized in Article 1 paragraph (1) of the Draft Criminal Code, which stipulates: there is no act that can be subject to penal sanction and/or treatment except by the force of the law that existed before the act was committed. Some of the main ideas are:

a. 'Criminal act' is an act that is contrary to the statute criminal law ('strafbaar feit' / 'mala prohibita');

b. "A criminal act" is an act that is subject to penal sanction and/or treatment.

Here is a conceptual classification: (1) 'prohibited acts' based on living law an additional penalty, namely 'fulfillment of local customary obligations' and (2) 'criminal acts' based on statute criminal law with the threat of the main penalty and/or additional penalties. The equivalence levels for 'prohibited acts' and 'criminal acts' are as follows:

a. the phrase "the statute law does not reduce the validity of the living law" means that there is no process of reducing or decreasing the level of enforceability of the living law. There is no degradation process for the quality of the living law's validity. Living law is still and in effect. The status of "statute law" and "living law " is equal;

b. "A prohibited act" is an act that is contrary to the living law, while a "criminal act" is an act that is contrary to the statute of criminal law;

c. The principle of general law recognized by civilized nations, as a concept of international law, raises the position of 'living law' whose enactment is local, upgraded to an international level;

d. The general principle of law recognized by civilized nations as a critical norm and a touchstone for the validity of 'living law' emphasizes that if the general principle of law recognized by civilized nations is in line with 'the living law', so the living law is considered to have the force.

The inequalities of 'prohibited acts' and 'criminal acts' are as follows:

a. "A criminal act" is an act that is subject to a principal penalty (including additional penalty) and/or treatment, while a "prohibited act" is only punishable by an additional penalty in the form of "fulfillment of local customary obligations";

b. 'Prohibited act' and 'fulfillment of local customary obligations' as concepts of equal position are degraded because the 'fulfilling local customary obligations' is only positioned as additional penalties and is only a complement to the principal penalties in 'criminal acts'. "Fulfillment of local customary obligations" is only granted if the objective of the principal penalty is not sufficient to achieve the objectives of the principal penalty;

c. "The living law" which has occupied an equal position with "The principle of general law recognized by civilized society", should in all aspects and facets be equal, especially in the case of penal sanction;

d. There has been a 'leveling down' on the concept of punishment on a 'prohibited act'. It should be that according to the perspective of 'general law principles recognized by civilized nations', 'prohibited acts' and 'criminal acts' should be at the same level;

e. There is a contradiction in concept, on one hand 'prohibited acts' based on 'living law' and 'criminal acts' based on statute criminal law are equivalent, while on the other hand 'prohibited acts' 'who is threatened with' fulfillment of local customary obligations', is only given the position of additional penalty, only a compliment if the principal penalty's objectives are not achieved;

f. There is a mistake in thinking that "fulfillment of local customary obligations" in "prohibited acts" is only positioned as an additional penalty to the principal penalty of "criminal acts". It is impossible for the punishment of "fulfillment of local customary obligations" to only be given if the main purpose of the principal penalty is insufficient, because for "prohibited acts" there is no principal penalty. Considering that "prohibited acts" and "criminal acts" have different qualifications, each of which is contrary to the living law as well as statute criminal law. This means that each has its punishment purpose. It is impossible for a "prohibited act" that is punishable by "fulfillment of local customary obligations" to 
qualify as an additional penalty, without the existence of the principal penalty. The construction of a 'prohibited act', as a separate qualification for an act, is not recognized as the principal penalty, but only known as an additional penalty (fulfillment of local customary obligations). There is a logic that is not connected, how can there be additional penalty without the principal penalty. This is different from the concept of a 'criminal act', which implements a principal penalty threat. If necessary, a 'criminal act' can be added with additional penalties (one of which is 'fulfillment of local customary obligations'), intending to fulfill the main criminal objectives. In essence, there must be a principal penalty threat, only then an additional penalty is given. The concept of 'criminal acts' - 'principal penalty' - 'additional penalty' is not known in the concept of 'prohibited act'. The concept of 'prohibited act' only recognizes 'prohibited act''additional penalty'.

\section{Conclusion}

The conclusion of the discussion on the formulation of the legal problem is that it is true that there has been a degradation in the concept of 'prohibited act' compared to 'criminal act'. The arguments for degradation are as follows:

a. 'Prohibited acts' are only punishable by additional penalties, in the form of 'fulfillment of local customary obligations', while 'criminal acts' are punishable with the principal penalty (including additional penalties) and/or treatment;

b. "Fulfillment of local customary obligations" is only positioned as a supplementary and complementary punishment to the principal penalty in a "criminal act", even though "prohibited act" and "criminal act" are concepts of equal position;

c. "Prohibited acts" and "criminal acts" have different qualifications of conduct. "A prohibited act" is punishable because it is contrary to "the living law", while a "criminal act" is punishable because it was contrary to statute criminal law. This means that each has its punishment purpose. It makes no sense if there is a construction that 'fulfillment of local customary obligations' in 'prohibited acts' is positioned as a supplementary and complementary punishment to the principal penalty in 'criminal acts', especially with the clause that 'fulfillment of local customary obligations' is only given if the objective the principal penalty has not been achieved. It is impossible for the punishment of 'fulfillment of local customary obligations' (as an additional penalty) for 'prohibited acts' to be qualified as a compliment and to fulfill the principal penalty purpose, while in 'prohibited acts' there is no principal penalty;

d. In the correct construction, a "criminal act" is punishable by the principal penalty. If necessary, additional penalties can be given (one of which is 'fulfillment of local customary obligations'). The purpose of additional penalties is to fulfill the principal penalty objectives. This means that there must be a principal penalty threat, only then an additional penalty is given. The construction for a 'prohibited act', as a separate qualification for an act in itself, is not recognized as the principal penalty, but only known as an additional penalty (fulfillment of local customary obligations). There is a logical fallacy, there can be no additional penalty without the principal penalty.

\section{References \\ Legislation:}

The Indonesia Criminal Code (Kitab Undang-Undang Hukum Pidana)

Draft of the Indonesia Criminal Code (Rancangan Kitab Undang-Undang Hukum Pidana)

Journal Articles:

Marlina, Perlindungan Hak Buruh Migran Oleh Negara Dalam Kedudukannya Sebagai Subyek Hukum Internasional, Pandecta, Volume 8. Nomor 2. Juli 2013

White, Justice Margaret, Equity-A General Principle of Law Recognised by Civilised Nation?, QUTLJJ, Vol 4 No 1

Yuherawan, Deni SB, Kritik Ideologis Terhadap Dasar Kefilsafatan Asas Legalitas Dalam Hukum Pidana, Jurnal Dinamika Hukum, Vol.12 No 2, Mei 2012

\section{Internet:}

Cambridge Dictionary, Retrived from: https:/dictionary.cambridge.org/dictionary/english/degradation -, https://dictionary.cambridge.org/example/english/civilized-nation

Collins Dictionary, Retived from: https://www.collinsdictionary.com/dictionary/english/civilized

Dosen Bahasa.com, Retrived from: https://dosenbahasa.com/contoh-kalimat-gramatikal-dan-leksikal

European Courtof Human Rights, Council of Europe, European Conventionon Human Rights, Retrived from: https://www.echr.coe.int/documents/convention_eng.pdf

Google.com, Retrived from: https://www.google.com/search?q=arti+gramatikal

------, Retrived from: https://www.google.com/search?q=arti+gramatikal

International Environmental Law, General Principles of Law Recognised by Civilised. Nations, Retrived from: 
https://www.soas.ac.uk/cedep-demos/000_P514_IEL_K3736-Demo/unit1/page 22.htm

International Legal Research Tutorial, General Principles of Law, Retrived from: https://law.duke.edu/ilrt/cust_law_10.htm

KBBI Online, Retrived from: https://kb bi.web.id/gramatikal

-------, https://kbbi.web.id/kadar-2

------, https://kbbi.web.id/degradasi

KBBI Online, Retrived from: https:/www.kamusbesar.com/takaran

Merriam-Webmaster, Retrived from: https:/www.merriam-webster.com/dictionary/degradation

Oxford

Public

International

Law,

Retrived

from: https:/opil.ouplaw.com/view/10.1093/law:epil/9780199231690/ law-9780199231690-e1748

Oxford Reference,

Retrived

from: https://www.oxfordreference.com/view/10.1093/oi/authority.20110803095847143

United Nations, Statute of the International Court of Justice, 18 April 1946, Retrived from: https://www.refworld.org/docid/3deb4b9c0.html

United Nations Human Rights, Office of the High Commissioner, International Covenant on Civil and Political Rights, Retrived from: https://www.ohchr.org/en/professionalinterest/pages/ccpr.aspx 